University of Montana

ScholarWorks at University of Montana

\title{
Unexpected Changes in Soil Phosphorus Dynamics Along Pasture Chronosequences in the Humid Tropics
}

\author{
Alan R. Townsend \\ Gregory P. Asner \\ Cory C. Cleveland \\ The University of Montana, cory.cleveland@umontana.edu \\ Margaret E. Lefer \\ Mercedes M. C. Bustamante
}

Follow this and additional works at: https://scholarworks.umt.edu/decs_pubs

Part of the Ecology and Evolutionary Biology Commons Let us know how access to this document benefits you.

\section{Recommended Citation}

Townsend, Alan R.; Asner, Gregory P.; Cleveland, Cory C.; Lefer, Margaret E.; and Bustamante, Mercedes M. C., "Unexpected Changes in Soil Phosphorus Dynamics Along Pasture Chronosequences in the Humid Tropics" (2002). Ecosystem and Conservation Sciences Faculty Publications. 6.

https://scholarworks.umt.edu/decs_pubs/6

This Article is brought to you for free and open access by the Ecosystem and Conservation Sciences at ScholarWorks at University of Montana. It has been accepted for inclusion in Ecosystem and Conservation Sciences Faculty Publications by an authorized administrator of ScholarWorks at University of Montana. For more information, please contact scholarworks@mso.umt.edu. 


\title{
Unexpected changes in soil phosphorus dynamics along pasture chronosequences in the humid tropics
}

\begin{abstract}
Alan R. Townsend, ${ }^{1}$ Gregory P. Asner, ${ }^{2,3}$ Cory C. Cleveland, ${ }^{1}$ Margaret E. Lefer, ${ }^{4,5}$ and Mercedes M. C. Bustamante ${ }^{6}$

Received 21 March 2001; revised 16 October 2001; accepted 26 November 2001; published 6 September 2002.

[1] Phosphorus $(\mathrm{P})$ is widely believed to limit plant growth and organic matter storage in a large fraction of the world's lowland tropical rain forests. We investigated how the most common land use change in such forests, conversion to cattle pasture, affects soil $\mathrm{P}$ fractions along pasture chronosequences in the central Brazilian Amazon and in southwestern Costa Rica. Our sites represent a broad range in rainfall, soil type, management strategies, and total soil P (45.2-1228.0 $\mu \mathrm{g} \mathrm{P} / \mathrm{g}$ soil), yet we found some unexpected and at times quite similar changes in soil $\mathrm{P}$ in all sites. In the Brazilian sites, where rainfall is relatively low and pasture management is more intense than in the Costa Rican sites, significant losses in total soil $\mathrm{P}$ and soil organic carbon (SOC) were seen with pasture age on already P-deficient Oxisol and Entisol soils. However, P losses were from inorganic soil P fractions, while organic forms of soil $\mathrm{P}$ remained constant or increased with pasture age, despite the declines in SOC. In Costa Rica, SOC remained constant across the Oxisol sites and increased from forest to pasture on the Mollisols, while soil organic P increased with pasture age in both sequences. INDEX TERMS: 1615 Global Change: Biogeochemical processes (4805); 1625 Global Change: Geomorphology and weathering (1824, 1886); 1630 Global Change: Impact phenomena; 1699 Global Change: General or miscellaneous; KEYWORDS: phosphorus, soils, land use change, pastures, tropics
\end{abstract}

Citation: Townsend, A. R., G. P. Asner, C. C. Cleveland, M. E. Lefer, and M. M. C. Bustamante, Unexpected changes in soil phosphorus dynamics along pasture chronosequences in the humid tropics, J. Geophys. Res., 107(D20), 8067, doi:10.1029/2001JD000650, 2002.

\section{Introduction}

[2] Ecosystems worldwide are undergoing unprecedented rates of land conversion and land use change [Meyer and Turner, 1992; Ojima et al., 1994]. Land management practices such as fire, grazing, tillage, and fertilizer application, among others, affect ecosystem composition, the distribution of organic matter, and a variety of nutrient cycling processes, including losses of limiting and essential elements to atmospheric and aquatic realms [e.g., Ewel et al., 1991; Reiners et al., 1994; de Moraes et al., 1996; Matson et al., 1997; Neill et al., 1997]. The most dramatic recent land use changes have been centered in tropical and subtropical forested ecosystems [Skole and Tucker, 1993; Houghton et al., 2000], where deforestation now removes roughly $2 \%$ of the remaining forest cover per year [Williams

\footnotetext{
${ }^{1}$ Institute of Arctic and Alpine Research and Department of Environmental, Population and Organismic Biology, University of Colorado, Boulder, Colorado, USA.

${ }^{2}$ Department of Geological Sciences and Environmental Studies Program, University of Colorado, Boulder, Colorado, USA.

${ }^{3}$ Now at Carnegie Institution of Washington, Stanford, California, USA.

${ }^{4}$ Institute of Arctic and Alpine Research, University of Colorado, Boulder, Colorado, USA.

${ }^{5}$ Now at Stratus Consulting, Boulder, Colorado, USA.

${ }^{6}$ Departament de Ecologia, Universidade de Brasília, Brasília-DF, Brazil.
}

Copyright 2002 by the American Geophysical Union. 0148-0227/02/2001JD000650 and Chartres, 1991; Nepstad et al., 1999], most of which becomes cattle pasture [Fearnside, 1996].

[3] The biogeochemical consequences of land use change in the tropics are potentially quite different from those in temperate regions, in large part because tropical ecosystems frequently occur on extremely old soils. The combination of greater soil age along with a warm, often wet climate, leads to highly weathered soils that are typically depleted in phosphorus (P) and base cations ( $\mathrm{Ca}, \mathrm{Mg}, \mathrm{K})$, rich in iron and aluminum oxides, and of variable charge [Uehara and Gillman, 1981; Sollins et al., 1988; Bruijnzeel, 1991]; these are the Oxisols and Ultisols that dominate many tropical regions. Carbon uptake and storage in ecosystems on such soils are often limited by phosphorus and/or base cation supply [Vitousek and Sanford, 1986; Cuevas and Medina, 1988; Herbert and Fownes, 1995; Vitousek and Farrington, 1997]. Thus any land use driven changes in P and/or base cation availability may be central to predicting the sustainability of cleared land, as well as land-atmosphere exchanges of carbon and trace gases following forest conversion.

[4] Phosphorus limitation, in particular, is believed to be common in tropical forests on old soils, and the constraints imposed by low P availability are a widely recognized problem in tropical agriculture [e.g., Sanchez et al., 1982]. Not only are many tropical soils relatively low in total soil $\mathrm{P}$, but their high iron and aluminum oxide content causes strong "fixation" of plant available inorganic $\mathrm{P}$ into more occluded forms that are thought to be largely unavailable to biota [Sanchez et al., 1982; Uehara and Gillman, 1981].

LBA $34-1$ 
Thus soil organic matter (SOM) and soil organic $\mathrm{P}$ are important to tropical soil fertility, both as a source of $\mathrm{P}$ at biotic timescales, and potentially as a buffer against $\mathrm{P}$ fixation by clay minerals [Tiessen et al., 1994; Afif et al., 1995; Guggenberger et al., 1996]. Finally, because primary mineral sources of $\mathrm{P}$ have been depleted in many old tropical soils, and inputs of $\mathrm{P}$ from the atmosphere are much lower than are those for other key rock-derived elements [Graham and Duce, 1979; Chadwick et al., 1999], any losses of $P$ during and after deforestation may have long-term consequences for productivity and community composition well after cleared lands are abandoned.

[5] Slash-and-burn clearing for pasture initially creates a pulse of plant-available nutrients, including $\mathrm{P}$, as the large pools held in biomass are released to the soil environment. Burning and subsequent ash deposition not only create a nutrient pulse, but also elevate soil $\mathrm{pH}$, which decreases the strength of $\mathrm{P}$ sorption and occlusion reactions [Anghinoni et al., 1996; Beauchemin et al., 1996]. However, this initial pulse of fertility is typically short-lived, and significant $\mathrm{P}$ losses can occur during and just after deforestation via transport of $\mathrm{P}$ in particulate matter [Kauffman et al., 1995, 1998]. In addition, there is evidence that $P$ constraints already present in undisturbed tropical soils are exacerbated by prolonged use of cleared lands [Tiessen et al., 1992]. It is not clear, however, whether this pattern is due to actual losses of $\mathrm{P}$ from the system, or to a redistribution of total soil P from more labile to more recalcitrant forms. The fact that labile forms of $\mathrm{P}$ are relatively immobile in soils suggests that the latter transformations may be more likely.

[6] Recent work by our group near Santarém, Pará, in the central Amazon showed significant declines in foliar and labile inorganic soil $\mathrm{P}$ with pasture age, and these depressions in $\mathrm{P}$ cycling were tightly correlated with declines in leaf area index and grass productivity [Asner et al., 1999]. As for many other pasture chronosequences [Davidson et al., 1995], we also observed significant decreases in soil organic matter with pasture age. Thus our original hypothesis was that declines in SOM would be accompanied by increased mineralization of soil organic $P$, creating a pulse of inorganic $\mathrm{P}$ that was highly susceptible to occlusion by clay minerals in the iron-and aluminum-oxide-rich Oxisols that are common in Amazonia (Figure 1). This net transfer of $\mathrm{P}$ from organic to occluded forms would feed back toward even greater $\mathrm{P}$ limitation, potentially driving declines in pasture productivity.

[7] However, precipitation, soil types and management strategies vary considerably across the tropics, even when restricting the focus to pastures alone, and not all land clearing takes place on old, high-clay Oxisols and Ultisols. For example, in the Santarém region significant areas of pasture are found on highly sandy soils in which the capacity for $\mathrm{P}$ fixation is low, and we also observed strong declines in SOM and plant-available nutrients (including P) with pasture age on such soils [Asner et al., 1999]. For the sandy soils, we hypothesized that their low $\mathrm{P}$ fixation capacity might cause pulses of inorganic $\mathrm{P}$ in young pastures to be more subject to loss from the site than would occur in high-clay soils, thereby leading to significant declines in total soil $\mathrm{P}$ as pastures age.

[8] It is also important to note that not all aging pastures show large declines in soil organic matter or productivity. For

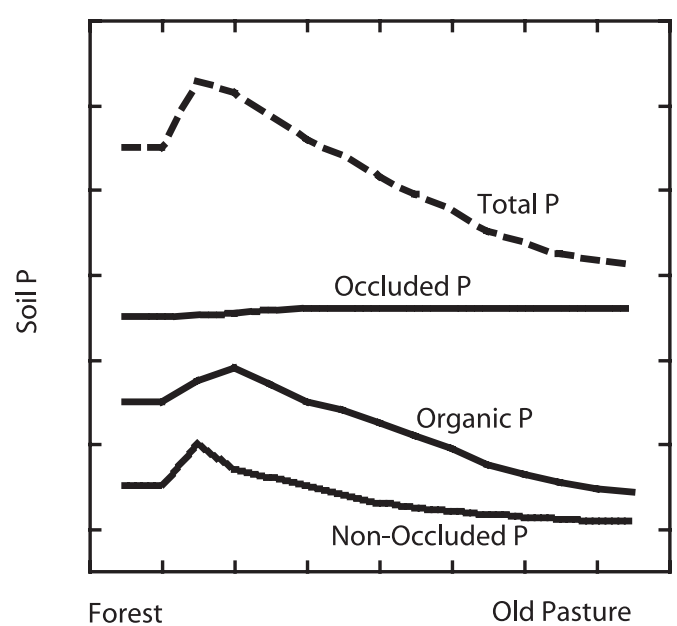

Figure 1. Hypothetical model for changes in soil $\mathrm{P}$ fractions following conversion of moist tropical forest to cattle pasture, where declines in total soil organic matter (SOM) are seen. We predicted that $\mathrm{P}$ mineralized during the loss of SOM would be increasingly vulnerable to occlusion by mineral surfaces of soils, because of both decreased SOM content and periods of relatively low plant uptake immediately following burning or during the drier months. Thus, over time an artificially elevated rate of $\mathrm{P}$ occlusion would further exacerbate $\mathrm{P}$ limitation, creating declines in plant available and organic $\mathrm{P}$ and plant production, which in turn would feed back to even greater P impoverishment and overall pasture degradation.

example, Neill et al. [1997] reported stable to even increasing SOM pools with pasture age along chronosequences in Rondônia. More recently, Garcia-Montiel et al. [2000] described a pattern of increases in soil organic $\mathrm{P}$ and declines in occluded soil $\mathrm{P}$ with pasture age in these same sites. Thus it appears that where environmental conditions or management practices maintain or even increase SOC in soils following forest to pasture conversion, concomitant maintenance or augmentation of soil organic P may also occur.

[9] Again, our hypothesis for the Santarém sites was that we would see very different patterns in soil $\mathrm{P}$ than those reported by Garcia-Montiel et al. [2000]. We observed decreases in SOC pools along pasture chronosequences near Santarém, and thus we expected to find declines in soil organic $\mathrm{P}$, and increases in occluded $\mathrm{P}$ in the Oxisols. Essentially, our working model was that changes in soil $\mathrm{P}$ fractions would be related to those in SOM. Where climate, soil type and/or management strategies do not create SOM losses, we did not expect losses in soil organic P and increases in occluded $\mathrm{P}$, but where SOM losses do occur, we predicted a net transfer from organic to occluded pools with pasture age on high clay soils, and a loss of soil $\mathrm{P}$ in soils with a low clay content.

[10] Finally, due to the wide range in climate, soils, and management across the tropics, we chose to search for a second set of pasture chronosequences where all three variables were considerably different from those in the Santarém area. Our goal here was to test for any consistent, general patterns in pasture soil $\mathrm{P}$ dynamics that transcended the wide range in potential driving variables. Portions of 
lowland Central America have higher rainfall and shorter dry seasons than in any part of the Amazon, large gradients in soil type from very young, highly fertile soils to old Oxisols such as those found in Amazonia, and management practices in which burning is rarely used. Thus we located a second set of sites with such characteristics in southwest Costa Rica.

\section{Methods}

2.1. Study Sites

2.1.1. Brazil

[11] The Brazilian sites consist of two pasture chronosequences located on two ranches south of Santarém, Pará, and east of the Tapajós River $\left(3^{\circ} 16^{\prime} \mathrm{S} 54^{\circ} 56^{\prime} \mathrm{W} ; 3^{\circ} 8^{\prime} \mathrm{S}\right.$ $54^{\circ} 40^{\prime} \mathrm{W}$ ). Mean annual rainfall is $2000 \mathrm{~mm}$, the bulk of which occurs between January and May, and mean annual temperature is $25^{\circ} \mathrm{C}$. All sites are on upland terra firma that has pockets of relic depositional surfaces, creating a mix of high clay Oxisols and highly sandy Entisols [Parrotta et al., 1995; Silver et al., 2000]. We established one chronosequence of pastures on the Oxisols dating 2, 7 and 15 years since conversion, and a second trio of sites (1,7 and 15 years old) on the sandy Entisols. Five of the six pastures were on a single ranch; the 2-year-old Oxisol pasture was the exception. Three of the sites (1 year Entisol, 2 and 7 year Oxisols) were dominated by the common introduced pasture grass Brachyaria brizantha; the other three sites were characterized by a second common introduced grass, Pennesetum clandestinum. All pastures were formed from primary forest. Some woody invaders, notably Solanum paniculatum, were sparsely distributed in some of the sites. All but the two youngest pasture sites had been burned since conversion as a means for controlling woody pioneer species, with one postclearing burn in each of the two 7-year-old pastures, and two such burns in the two oldest pastures. Cattle stocking rates have varied over time in the 4 older pastures between 0.25 and 0.5 cows $\mathrm{ha}^{-1} \mathrm{yr}^{-1}$; the two youngest pastures in each sequence had not yet been grazed. Relief in all sites is minimal, and none of the pastures have been fertilized.

\subsubsection{Costa Rica}

[12] We established a second pair of chronosequences in southwest Costa Rica. The sites are at $8^{\circ} 43^{\prime} \mathrm{N}, 83^{\circ} 37^{\prime} \mathrm{W}$, approximately $5 \mathrm{~km}$ inland of the town of Agujitas, which is located at Drake Bay on the Osa Peninsula. The entire Osa Peninsula was formed in three large seafloor volcanic events between roughly 75 and 40 million years ago, but some parts of the region were below sea level in more recent geologic eras [Berrange and Thorpe, 1988]. This created a wide range in parent material ages and subsequent soil types, from old, highly weathered Oxisols to highly fertile alluvial Mollisols of Quaternary origin. Again, we chose sites at both ends of this soil gradient: primary forest, a 5-year-old pasture, and a 20-year-old pasture on Oxisols, and a primary forest and 20-year-old pasture on Mollisols. The high fertility of the Mollisols led to extensive clearing on these soils some time ago, thus recently converted pastures are rare to nonexistent. All five sites were within a few hundred meters of each other; the Oxisol sites had a consistent and gentle relief $(<10 \%)$ but continue to uplands with slopes of $40 \%$ or greater, while the Mollisol sites occupy lowland areas of minimal relief. The two forest sites were typical of the region in their extraordinary species diversity; no species dominated the forest canopy. The three pasture sites were dominated by the common introduced grass Panicum maximum. All pastures were cleared by slash and burn methods, but none of the pastures had been burned since initial clearing; instead, weedy ingrowth in this region is typically controlled via cutting and the use of herbicides. Stocking rates for the two oldest pastures have been relatively low at less than 0.25 cows $\mathrm{ha}^{-1} \mathrm{yr}^{-1}$; they are also likely low but are not known for the 5-year-old Oxisol. None of the pastures have been fertilized.

\subsection{Soil Collection and Analyses}

[13] Ten soil samples per site were collected from $0-10$ $\mathrm{cm}$ depth along random intervals within $100 \mathrm{~m}$ transects. Soils were air dried, sieved at $2 \mathrm{~mm}$, and analyzed for total carbon, nitrogen, phosphorus, $\mathrm{P}$ fractions, texture and $\mathrm{pH}$. Bulk density measurements were determined using an excavation method in which the volume of removed soil is measured by replacing it with a known volume of sand, and the soil removed is dried and weighed. Subsamples for total carbon and nitrogen were ground to a fine powder and analyzed using a combustion-reduction elemental analyzer (CE Elantech, Lakewood, New Jersey). Total P analyses were performed by digesting $5 \mathrm{~g}$ of sieved, air-dried soil in $\mathrm{H}_{2} \mathrm{SO}_{4}$ and $\mathrm{H}_{2} \mathrm{O}_{2}$ [Parkinson and Allen, 1975]; the digested solution was then analyzed for phosphate concentrations using a flow-injection autoanalyzer (OI Analytical, College Station, Texas). Because the higher bulk densities that are often found in increasingly older pastures are typically due to soil compaction, total soil values for all elements in pasture sites were corrected for compaction as described by Veldkamp [1994].

[14] Approximately $1 \mathrm{~g}$ of soil from 8 of the 10 cores from each site was analyzed for soil $\mathrm{P}$ fractions using the modified Hedley fractionation technique described by Tiessen and Moir [1993]. Briefly, the soil was subjected to a series of extractions in the following order: a resin extraction (in water), bicarbonate, $0.1 \mathrm{M} \mathrm{NaOH}, 1 \mathrm{M} \mathrm{HCl}$, hot concentrated $\mathrm{HCl}$, and a final peroxide/sulfuric acid digest (residue fraction). Digests were also done on the solution following bicarbonate, $\mathrm{NaOH}$ and $\mathrm{HCl}$ extractions, and organic $\mathrm{P}$ in each fraction was determined by difference. Resin- and bicarbonate-extractable pools are the most labile forms of soil $\mathrm{P}$, and their sum is often taken as a proxy for readily available (labile) $\mathrm{P}$, as previous studies have shown that bicarbonate-extractable $\mathrm{P}$ is well correlated with plant growth [Bowman et al., 1978; Levy and Schlesinger, 1999]. The 1M $\mathrm{HCl}$ fraction is thought to reflect primary mineral $\mathrm{P}(\mathrm{Ca}-$ bound), while the remaining inorganic fractions are believed to distinguish P pools of varying recalcitrance, from weakly to strongly occluded [Tiessen and Moir, 1993; Cross and Schlesinger, 1995; Levy and Schlesinger, 1999]. In theory, the sum of all fractions at the end of the analyses should be equal to total soil $\mathrm{P}$, but we chose to do separate digests for total $\mathrm{P}$, as a check on the efficiency of the fractionation procedure. Phosphate concentrations in each fraction were determined using an Alpkem autoanalyzer. The protocol described by Tiessen and Moir [1993] requires that each fraction be neutralized via hand titration prior to MurphyRiley colorimetric analysis, but we avoided this time con- 
suming step by adjusting the normality of the sulfuric acid in the Alpkem color reagent. This adjustment is specific to each fraction, and calculated to achieve a mixture of sample and color reagent that creates the desired acidity at the detector. We tested subsets of each soil type against the standard neutralization methods, and found no significant differences between the two approaches for any fraction.

[15] Finally, statistical analyses of differences among sites and along each chronosequence were performed using the one-way ANOVA procedure in SPSS v.10.0 (SPSS Inc., Chicago, Illinois). Where significant trends were found, further analyses of differences between each site were evaluated using the same software to perform a post hoc Tukey's HSD test.

\section{Results}

[16] Percent soil $\mathrm{C}$ and $\mathrm{N}$ were higher in all five Costa Rican sites than in any of the Brazilian sites (Table 1; Tukey HSD $\mathrm{p}<0.05)$, but the higher soil bulk densities in Brazil indicate that total soil $\mathrm{C}$ and $\mathrm{N}$ pools were not consistently greater in Costa Rica (Table 1). Overall, total soil carbon values ranged from a maximum of $5.51 \mathrm{~kg} \mathrm{C} / \mathrm{m}^{2}$ in the Costa Rican Mollisol pasture, to a minimum of $2.00 \mathrm{~kg}$ $\mathrm{C} / \mathrm{m}^{2}$ in the oldest Brazilian Entisol pasture. Total soil carbon was similar in all Oxisols across both countries with the exception of the youngest Brazilian pasture, where soil $\mathrm{C}$ was significantly greater than in the other five Oxisol sites (Table 1; Tukey HSD p < 0.05). Soil carbon pools decreased with pasture age in both Brazilian chronosequences (Entisols: $\mathrm{F}=14.8, \mathrm{p}<0.001$; Oxisols: $\mathrm{F}=139.8, \mathrm{p}<0.001)$. In Costa Rica, $\%$ and total soil $\mathrm{C}$ values declined from forest to older pastures, but these declines were not significantly different for either chronosequence. Patterns in soil $\mathrm{N}$ followed those for soil $\mathrm{C}$.

[17] The range and patterns in soil $\mathrm{P}$ were more striking than for those in soil $\mathrm{C}$ and $\mathrm{N}$. Total soil $\mathrm{P}$ varied by more than an order of magnitude across all eleven sites, from a maximum of $81.0 \mathrm{~g} / \mathrm{m}^{2}$ in the 20 year Costa Rican Mollisol pasture, to a minimum of $6.5 \mathrm{~g} / \mathrm{m}^{2}$ in the 15 year Brazilian Entisol (Table 1). Soil $\mathrm{P}$ values in the Brazilian sites were all relatively low, and those in the Entisol pastures were much lower than values commonly reported in the literature [e.g., Cross and Schlesinger, 1995]. The effects of land use on total soil $\mathrm{P}$ were very different between the two countries. In the Costa Rica Oxisols, soil P ranged from $33.2 \mathrm{~g} / \mathrm{m}^{2}$ in the 20 year pasture to $29.0 \mathrm{~g} / \mathrm{m}^{2}$ in the adjacent forest (Table 1). A similar pattern was seen in the Mollisols, where soil $\mathrm{P}$ in the 20 -year-old pasture was $81.0 \mathrm{~g} / \mathrm{m}^{2}$, compared to $69.4 \mathrm{~g} / \mathrm{m}^{2}$ in its forest counterpart (Table 1). Soil P concentration also increased from forest to older pastures in each sequence, although the higher $\mathrm{P}$ pools and concentrations in the two old pastures were not significantly different from the forest values on either soil type (Figure 2).

[18] In Brazil, where soil $\mathrm{C}$ and $\mathrm{N}$ declined with pasture age, so did total soil P. Values in the two 15-year-old Oxisol and Entisol pastures were $27 \%$ and $40 \%$ lower, respectively, than in the youngest pastures on each sequence (Table 1). The decline was particularly noteworthy in the sandy Entisols, where decreases in soil P, assumed to be far less mobile than $\mathrm{C}$ and $\mathrm{N}$, were proportionately greater than those in the latter two elements (Table 1). Soil P concen- trations ( $\mu \mathrm{g} \mathrm{P} / \mathrm{g}$ soil) also declined significantly with pasture age in both Brazilian chronosequences (Figure 2).

[19] Not surprisingly, many of the soil P fractions also changed significantly along the land use gradients, but the general patterns did not support the hypothesis presented in Figure 1. Data for each fraction from the modified Hedley procedure are presented in Table 1, but the overall patterns are more easily seen by grouping the fractions into three categories similar to those described by Walker and Syers [1976]. These categories are: (1) nonoccluded P, equal to the sum of resin-extractable, bicarbonate inorganic and $\mathrm{NaOH}$ inorgnanic P fractions; (2) organic P (sum of all organic fractions); and (3) occluded $\mathrm{P}$, equal to the sum of $1 \mathrm{M} \mathrm{HCl}$, concentrated $\mathrm{HCl}$ and residue inorganic $\mathrm{P}$ fractions. We included the $1 \mathrm{M} \mathrm{HCl}$ fraction, which is thought to represent primary mineral $\mathrm{P}$, in the last grouped fraction not because it is occluded in the same sense as Fe-and Al-bound P, but because it is relatively low in all our sites, will not be readily available to biota at short timescales, and for ease of presentation. Overall, these divisions are useful for separating "biological" versus "geochemical" pools of soil P, as discussed by Cross and Schlesinger [1995].

[20] Some of the more surprising results from our analyses are shown in Figure 2, which depicts changes in the major P fractions along the four chronosequences. In both Brazilian sequences, despite significant declines in soil organic $\mathrm{C}$ and $\mathrm{N}$ with pasture age, soil organic $\mathrm{P}$ either increased (Oxisols) or remained unchanged (Entisols). As a percentage of total soil $\mathrm{P}$, soil organic $\mathrm{P}$ increased markedly along both chronosequences, rising from $25 \%$ to $39 \%$ on the Oxisols, and from $26 \%$ to $44 \%$ on the Entisols (Figure $3)$. The declines in total soil $\mathrm{P}$ seen in each Brazilian sequence were due to large decreases in the nonoccluded and occluded P fractions (Figure 2). The decline in occluded $\mathrm{P}$ was especially striking: this pool was $16 \%$ lower in the Oxisols and 59\% lower in the Entisols as compared to the youngest pasture on each sequence.

[21] In Costa Rica, organic P again increased significantly from forest to pasture in both chronosequences (Figure 2). Unlike Brazil, however, the major inorganic fractions did not decline with pasture age: both nonoccluded and occluded $\mathrm{P}$ were not significantly different between the primary forests and oldest pastures on each soil type (Figure 2).

\section{Discussion}

[22] Walker and Syers' [1976] model for P changes with soil development has led to a general notion that soil $\mathrm{P}$ in old tropical soils is mostly highly recalcitrant and immobile, a product of millions of years of intense weathering. In many respects, this general model has been proven accurate [e.g., Cross and Schlesinger, 1995; Crews et al., 1995], but our data suggest that land use disturbances can cause rapid and substantial changes in soil $\mathrm{P}$ fractions. In particular, while there are clearly differences in soil $\mathrm{P}$ responses across major gradients in soil type, climate and management, forest-to-pasture conversion does seem to cause two general and surprising trends. First, organic forms of soil P increase with pasture age, or at the very least do not decline, even in sites where large declines in total soil organic matter are observed (Figure 4). Second, despite stable or increasing organic $\mathrm{P}$ pools in the Brazilian sites, total $\mathrm{P}$ declined in 
Table 1. Surface Soil Carbon, Nitrogen, Phosphorus, Phosphorus Fractions, Texture, pH, and Bulk Density for Six Brazilian and Three Costa Rican Pastures and Two Costa Rican Primary Forests ${ }^{\mathrm{a}}$

\begin{tabular}{|c|c|c|c|c|c|c|}
\hline & \multicolumn{6}{|c|}{ Brazilian Sites } \\
\hline & $\begin{array}{l}2 \text { year } \\
\text { Oxisol }\end{array}$ & $\begin{array}{l}7 \text { year } \\
\text { Oxisol }\end{array}$ & $\begin{array}{c}15 \text { year } \\
\text { Oxisol }\end{array}$ & $\begin{array}{l}1 \text { year } \\
\text { Entisol }\end{array}$ & $\begin{array}{c}7 \text { year } \\
\text { Entisol }\end{array}$ & $\begin{array}{l}15 \text { year } \\
\text { Entisol }\end{array}$ \\
\hline Texture & $37 / 3 / 60$ & $39 / 2 / 59$ & $40 / 5 / 55$ & $89 / 4 / 7$ & $92 / 2 / 5$ & $91 / 4 / 5$ \\
\hline $\mathrm{pH}$ & 5.3 & 5.4 & 5.0 & 5.6 & 5.6 & 5.3 \\
\hline Soil C, \% & $4.35(0.1)$ & $2.28(0.04)$ & $2.02(0.1)$ & $1.85(0.1)$ & $1.54(0.2)$ & $1.4(0.04)$ \\
\hline Soil N, \% & $0.32(0.02)$ & $0.19(0.01)$ & $0.15(0.02)$ & $0.12(0.02)$ & $0.09(0.04)$ & $0.08(0.01)$ \\
\hline Soil P digest, ug/g & $173.8(14.8)$ & $135.8(6.7)$ & $127.4(6.1)$ & $75.3(3.2)$ & $52.3(4.3)$ & $45.2(2.1)$ \\
\hline Soil P sum of fractions, ug/g & 150.9 & 128.3 & 139.7 & 80.2 & 59.4 & 39.6 \\
\hline Bulk density, $\mathrm{g} / \mathrm{cm}^{3}$ & 1.2 & 1.5 & 1.5 & 1.4 & 1.4 & 1.4 \\
\hline Total $\mathrm{C}, \mathrm{kg} / \mathrm{m}^{2}$ & 5.2 & 2.7 & 2.4 & 2.7 & 2.2 & 2.0 \\
\hline Total $\mathrm{N}, \mathrm{kg} / \mathrm{m}^{2}$ & 0.4 & 0.2 & 0.2 & 0.2 & 0.1 & 0.1 \\
\hline Total $\mathrm{P}, \mathrm{g} / \mathrm{m}^{2}$ & 20.9 & 16.3 & 15.3 & 10.8 & 7.5 & 6.5 \\
\hline \multicolumn{7}{|l|}{$\mathrm{P}$ fraction, ug/g } \\
\hline Resin Pi & $8.6(3.5)$ & $7.5(0.4)$ & $7.8(1.1)$ & $6.8(1.2)$ & $3.4(0.8)$ & $1.4(0.1)$ \\
\hline Bicarb Pi & $2.9(1.7)$ & $1.8(0.1)$ & $2.1(0.8)$ & $2.5(0.4)$ & $0.6(0.2)$ & $0.2(0.1)$ \\
\hline Bicarb Po & $4.7(.9)$ & $3.9(0.3)$ & $7.5(0.8)$ & $4.9(0.4)$ & $3.4(0.3)$ & $2.8(0.2)$ \\
\hline $1 \mathrm{M} \mathrm{HCl}$ & $8.0(2.9)$ & $1.0(0.1)$ & $1.4(0.2)$ & $1.1(0.2)$ & $1.3(0.4)$ & $0.9(0.1)$ \\
\hline $\mathrm{NaOH} \mathrm{Pi}$ & $25.5(9.1)$ & $9.6(0.7)$ & $11.5(0.9)$ & $10.9(1.5)$ & $10.1(2.5)$ & $3.5(0.6)$ \\
\hline $\mathrm{NaOH} \mathrm{Po}$ & $22.6(9.8)$ & $20.3(1.2)$ & $31.0(2.5)$ & $12.3(0.5)$ & $13.5(1.2)$ & $11.4(1.0)$ \\
\hline Conc. $\mathrm{HCl} \mathrm{Pi}$ & $30.2(2.7)$ & $38.2(0.5)$ & $28.8(1.4)$ & $15.3(0.6)$ & $9.1(0.4)$ & $6.9(0.3)$ \\
\hline Conc. $\mathrm{HCl} \mathrm{Po}$ & $11.1(.6)$ & $12.2(0.7)$ & $14.9(2.2)$ & $3.6(0.1)$ & $3.2(0.5)$ & $3.0(0.4)$ \\
\hline \multirow[t]{3}{*}{ Residue } & $37.4(2.3)$ & $33.8(1.5)$ & $34.82(1.6)$ & $22.7(1.0)$ & $14.8(0.6)$ & $9.6(0.8)$ \\
\hline & \multicolumn{6}{|c|}{ Costa Rican Sites } \\
\hline & Oxisol Forest & 5 year Oxisol & 20 yea & & Mollisol Forest & 20 year Mollisol \\
\hline $\mathrm{pH}$ & 5.4 & 5.1 & & & 6.0 & 5.9 \\
\hline Soil C, \% & $6.45(0.2)$ & $5.4(0.1)$ & 4.96 & & $6.78(0.3)$ & $5.57(0.2)$ \\
\hline Soil N, \% & $0.56(0.03)$ & $0.47(0.02)$ & 0.43 & & $0.58(0.04)$ & $0.48(0.02)$ \\
\hline Soil P digest, ug/g & $557.1(18.5)$ & $566.5(35.9)$ & 639.3 & & $1051.4(43.1)$ & $1228.0(88.7)$ \\
\hline Soil P sum of fractions, ug $/ \mathrm{g}$ & 495.9 & 475.3 & & & 887.8 & 1099.8 \\
\hline Bulk density, $\mathrm{g} / \mathrm{cm}^{3}$ & 0.5 & 0.6 & & & 0.7 & 1.0 \\
\hline Total $\mathrm{C}, \mathrm{kg} / \mathrm{m}^{2}$ & 3.4 & 2.8 & & & 4.5 & 3.7 \\
\hline Total $\mathrm{N}, \mathrm{kg} / \mathrm{m}^{2}$ & 0.3 & 0.2 & & & 0.4 & 0.3 \\
\hline Total $\mathrm{P}, \mathrm{g} / \mathrm{m}^{2}$ & 29.0 & 29.5 & & & 69.4 & 81.0 \\
\hline \multicolumn{7}{|l|}{$\mathrm{P}$ fraction, ug/g } \\
\hline Resin $\mathrm{Pi}$ & $4.2(0.4)$ & $4.1(0.4)$ & 2.0 & & $8.9(0.9)$ & $9.4(2.7)$ \\
\hline Bicarb Pi & $3.4(0.1)$ & $3.2(0.1)$ & 2.7 & & $5.1(0.5)$ & $7.4(1.7)$ \\
\hline Bicarb Po & $13.7(0.6)$ & $16.3(0.8)$ & 20.3 & & $27.6(1.1)$ & $33.5(0.9)$ \\
\hline $1 \mathrm{M} \mathrm{HCl}$ & $1.9(0.1)$ & $1.5(0.04)$ & 1.9 & & $23.3(1.7)$ & $53.7(19.5)$ \\
\hline $\mathrm{NaOH} \mathrm{Pi}$ & $53.9(2.0)$ & $69.6(3.7)$ & 56.7 & & $76.3(2.4)$ & $161.9(40.0)$ \\
\hline $\mathrm{NaOH}$ Po & $77.5(1.6)$ & $102.6(5.4)$ & 106.9 & & $167.2(11.1)$ & $217.5(20.3)$ \\
\hline Conc. $\mathrm{HCl} \mathrm{Pi}$ & $167.0(3.8)$ & $149.0(11.6)$ & 189.8 & & $209.4(7.0)$ & $199.5(26.3)$ \\
\hline Conc. $\mathrm{HCl}$ Po & $19.0(3.0)$ & $12.2(2.5)$ & 41.5 & & $38.7(3.7)$ & $38.0(4.0)$ \\
\hline Residue & $155.4(0.8)$ & $116.8(8.0)$ & 198.8 & & $370.0(16.2)$ & 378.9 (26.5) \\
\hline
\end{tabular}

${ }^{\text {a }}$ Phosphorus fractions are those defined by the modified Hedley technique as described by Tiessen and Moir [1993]. Values in parentheses are standard errors, and represent 10 samples per site for total soil $\mathrm{C}, \mathrm{N}$ and $\mathrm{P}$, and 8 samples per site for the $\mathrm{P}$ fractions. Total soil $\mathrm{P}$ values are shown from a $\mathrm{H}_{2} \mathrm{SO}_{4}{ }^{+}$ $\mathrm{H}_{2} \mathrm{O}_{2}$ digest ("Soil $\mathrm{P}$ digest") and from the sum of all Hedley fractions ("Soil P sum of fractions").

each pasture sequence, and much of this decline was in the occluded fraction.

[23] While $\mathrm{P}$ is often described as a relatively immobile nutrient, several avenues for P loss during and after deforestation do exist. First, burning of forest and pasture biomass can cause significant $\mathrm{P}$ losses in particulate form [Kauffman et al., 1995, 1998]. Second, between burning and the establishment of full grass cover, pasture soils can be subject to high erosion losses, although the flat terrain in our Brazilian sites makes it unlikely that erosion played a major role in the P declines. Third, some P may be lost via leaching, again most likely during the interval between clearing and pasture establishment. The limited data that does exist on P leaching suggests it is likely to be quite low [Lesack and Melack, 1996], but the exception may be highly sandy soils such as the Brazilian Entisols described here. Such leaching losses might also be exacerbated by relatively shallow rooted pasture grasses (as compared to the native forest), in that $\mathrm{P}$ leached from surface horizons is then less likely to be returned to the surface via plant uptake.

[24] Finally, P can be lost from the site in cattle biomass. We do not have direct estimates of P loss in cattle from our sites, but based on estimates from other Amazonian pastures, we believe $\mathrm{P}$ export in cattle only accounts for a minor fraction of the $\mathrm{P}$ losses we observed in the two Brazilian chronosequences. Dias-Filho et al. [2001] estimated $\mathrm{P}$ exports in cattle at $0.5 \mathrm{~kg} / \mathrm{ha} / \mathrm{yr}$. Stocking rates in our pastures are relatively low [Asner et al., 1999], especially on the Entisols, thus we believe P losses from our sites are unlikely to be higher than this value. A $0.5 \mathrm{~kg} / \mathrm{ha} / \mathrm{yr}$ export of $\mathrm{P}$ translates to $12 \%$ of the total $\mathrm{P}$ decline observed 

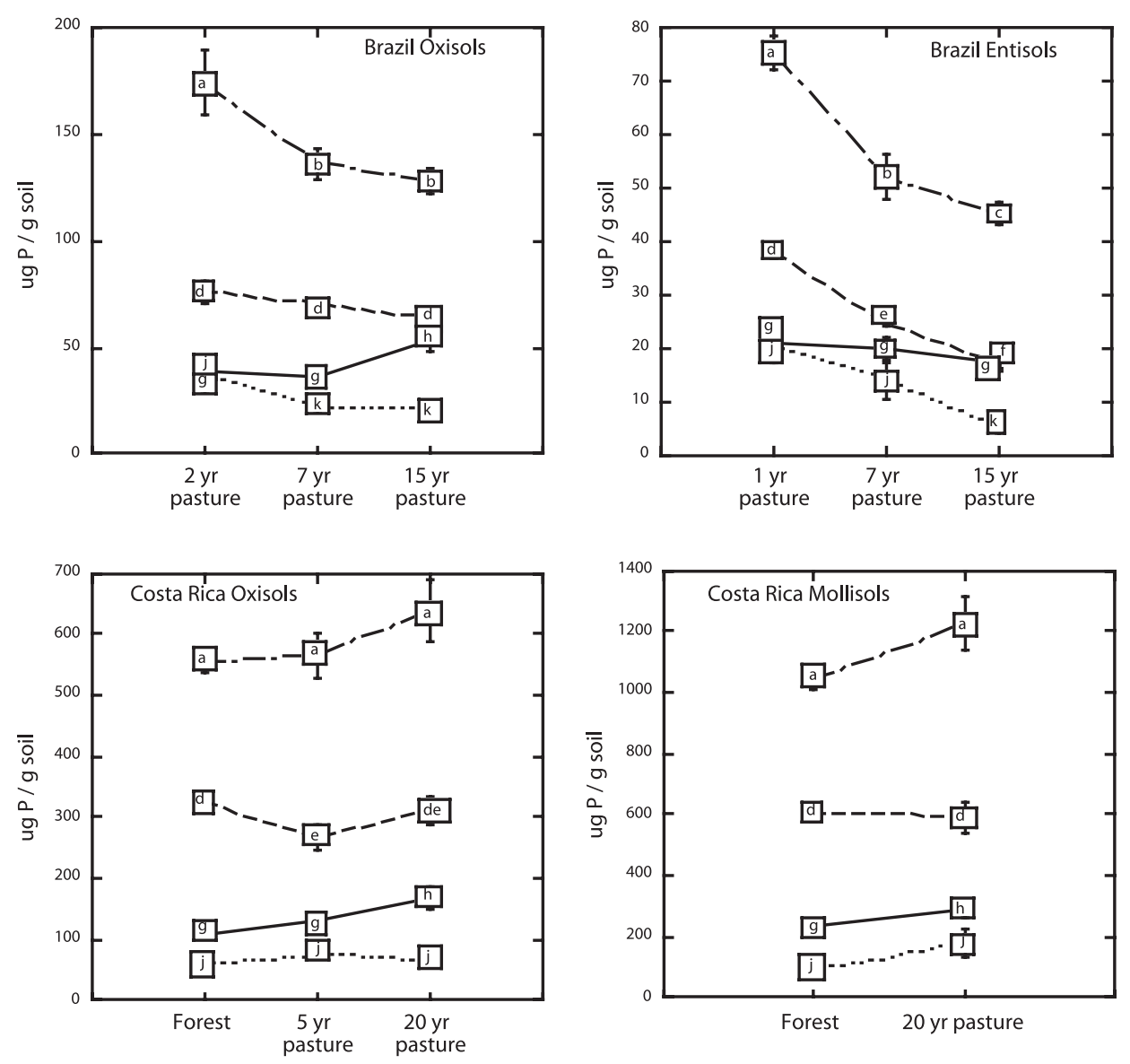

Figure 2. Nonoccluded (dotted line), organic (solid line), occluded (small dashed line) and total (large dashed line) soil $\mathrm{P}$ with pasture age along two Brazilian and two Costa Rican chronosequences. All values are sums of fractions from a modified Hedley fractionation procedure as described in the text. Nonoccluded $\mathrm{P}$ is equal to the sum of resin-, bicarbonate- and $\mathrm{NaOH}$-extractable inorganic fractions; occluded $\mathrm{P}$ is the sum of the concentrated $\mathrm{HCl}$-extractable and residue inorganic fractions; and organic $\mathrm{P}$ is the sum of bicarbonate-, $\mathrm{NaOH}$-and concentrated $\mathrm{HCl}$-extractable organic fractions. Total soil $\mathrm{P}$ values here are those from the digest shown in Table 1; these values were used as a digest is subject to less error than is summing all Hedley fractions. Significant differences (Tukey HSD, $p<0.05$ ) along the chronosequence for a given fraction are denoted by different letters that are specific to each fraction: $\mathrm{a}-\mathrm{c}$, total P; $\mathrm{d}-\mathrm{f}$, occluded $\mathrm{P} ; \mathrm{g}-\mathrm{h}$, organic $\mathrm{P} ; \mathrm{j}-\mathrm{l}$, nonoccluded $\mathrm{P}$. Bars indicate standard errors; where error bars cannot be seen, they are smaller than the label box.

along the Brazilian Oxisol sequence, and $16 \%$ of that seen in the Entisols. Thus we believe that the bulk of the P loss must be occurring by other mechanisms.

[25] While not without recent precedence [Garcia-Montiel et al., 2000], the decline in occluded $\mathrm{P}$ was quite unexpected, and suggests that this fraction is not always as recalcitrant as is typically assumed. However, it's important to note that the most dramatic losses of total and "occluded" P were seen in the highly sandy Entisols, in which the capacity for $\mathrm{P}$ occlusion by iron and aluminum oxides is low. Thus, while concentrated $\mathrm{HCl}$ and sulfuric acid extractions do remove $\mathrm{P}$ from the Entisols that is not liberated earlier in the Hedley sequence, these pools almost certainly represent something very different in the Entisols than they do in high $\mathrm{Fe}$ and $\mathrm{Al}$ oxide Oxisols, and should probably not be thought of as occluded $\mathrm{P}$ in the classic sense. Instead, our data suggest that the bulk of inorganic soil $\mathrm{P}$ in these highly sandy Entisols may be relatively labile, and therefore able to change markedly following disturbance.

[26] In contrast, the Brazilian Oxisols have a high capacity for $\mathrm{P}$ occlusion, and yet total and occluded $\mathrm{P}$ also decline with pasture age along this chronosequence. These trends are perhaps more surprising than those in the Entisols, and harder to explain, but we offer two possibilities for the decline in occluded P. First, sorption and occlusion of labile, inorganic $\mathrm{P}$ is stronger at lower $\mathrm{pHs}$ [Lopez-Hernandez and Burnham, 1974; Afif et al., 1995; Guggenberger et al., 1996], and soil $\mathrm{pH}$ values typically increase following conversion of forest to pasture. We did not see such an increase in $\mathrm{pH}$ in Costa Rica, where burning is not used, but it has been reported for many other forest-pasture comparisons [e.g., Reiners et al., 1994], and soil $\mathrm{pH}$ values in Oxisol forests near our Brazilian pastures are considerably lower [Silver et al., 2000]. Where $\mathrm{pH}$ does rise following deforestation, it may cause a transfer of inorganic $\mathrm{P}$ from 

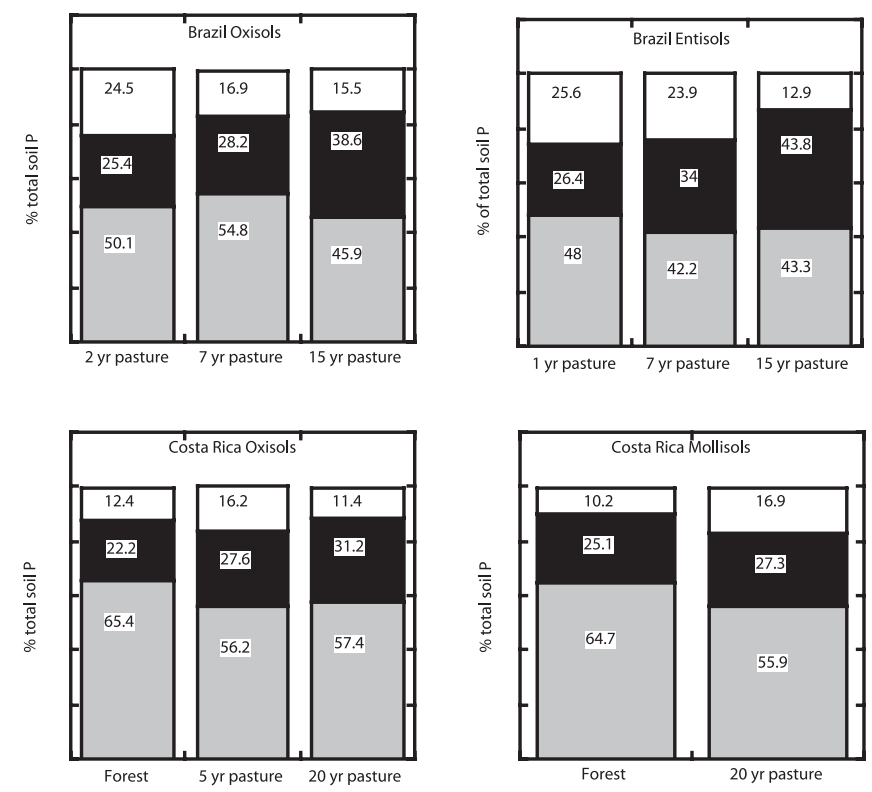

Figure 3. Nonoccluded, organic, and occluded soil $\mathrm{P}$ in six Brazilian and five Costa Rican sites expressed as a percentage of total soil $\mathrm{P}$ in each site. The white portions of the columns depict nonoccluded $\mathrm{P}$, the black portions represent organic $\mathrm{P}$, and the grey portions represent the occluded $\mathrm{P}$ fraction.

occluded to more labile forms. Second, soils under pasture are frequently subject to significant compaction, as evidenced by the increases in bulk density seen in our data and elsewhere [Veldkamp, 1994; de Moraes et al., 1996]. Such compaction can strongly limit oxygen availability in the soil, creating a more reducing environment [Chauvel et al., 1991; de Moraes et al., 1996], which could also lead to a net release of inorganic $\mathrm{P}$ from more to less occluded forms [Uehara and Gillman, 1981].

[27] Whatever the mechanism for the declines in occluded $\mathrm{P}$, its occurrence should create a pulse of $\mathrm{P}$ fertility as inorganic forms of $\mathrm{P}$ are liberated into plant-available forms. Yet, in the Brazilian chronosequences where the declines in occluded $\mathrm{P}$ were seen, we also observed decreases in the most labile forms of inorganic $\mathrm{P}$ (Figure 2 ), increases in foliar $\mathrm{C}: \mathrm{P}$ ratios in the pasture grasses, and decreases in aboveground biomass and productivity [Asner et al., 1999]. It therefore seems likely that the losses in productivity seen in both of the Brazilian pasture sequences were at least partly driven by a steady decline in $\mathrm{P}$ availability in soils that were P-poor prior to conversion. Finally, this apparent paradox in which there seems to be a source of new labile $\mathrm{P}$ from declines in occluded $\mathrm{P}$, and yet no evidence for increases in $\mathrm{P}$ fertility, is deepened by the observation of increases in soil organic $\mathrm{P}$ with pasture age.

[28] Organic forms of soil $\mathrm{P}$ are thought to be critical to tropical soil fertility, largely because labile, inorganic $\mathrm{P}$ is subject to occlusion by mineral surfaces of many tropical soils [e.g., Tiessen et al., 1994]. Thus one would expect an increase in soil organic $\mathrm{P}$, along with a decrease in occluded $\mathrm{P}$, to increase the $\mathrm{P}$ fertility of a given site. How then does one explain a pattern in which soil organic $\mathrm{P}$ increases and occluded P decreases on two very different soil types, yet plant-available forms of $\mathrm{P}$ also decrease, and the plants show strong signs of increasing P limitation? Moreover, when expressed as a percentage of soil mass, we found that while soil organic $\mathrm{C}$ decreases in all four chronosequences, soil organic $\mathrm{P}$ increases in three of those four, and remains stable in the Brazilian Entisols (Figure 4). Garcia-Montiel et al. [2000] also reported significant increases in soil organic $\mathrm{P}$, but in their sites, SOC did not decline with pasture age and they attributed the change in organic $P$ to new inputs of organic matter from productive, shallow rooted grasses. However, in our Brazilian sites soil organic $\mathrm{C}: \mathrm{P}$ ratios decline sharply in all four chronosequences and the dynamics of soil organic $\mathrm{P}$ are clearly decoupled from those in total organic matter (Figure 4).

[29] One possible explanation for the rise in organic $\mathrm{P}$ is that a significant amount of plant organic matter is passing through cattle in the pasture, much of which is then returned to the site as manure. Declining soil $\mathrm{P}_{\mathrm{i}}$ pools are in part feeding the creation of organic $\mathrm{P}$ in plant biomass; the fraction of this which is then returned to the soil in manure will have a much lower $C: P_{o}$ ratio than the plant tissue. Thus the presence of cattle may in part contribute to the apparent decoupling between soil organic P pools and total SOM.

[30] In addition, we believe that changes in the composition and/or function of the soil microbial community may be driving some of the patterns we observed. Since all forms of inorganic $\mathrm{P}$ either remain constant or decline with pasture age in our sites while organic $\mathrm{P}$ increases, it seems that the rate at which organic $\mathrm{P}$ is mineralized must decline. In other words, the increases in organic P are not simply due to new inputs because they are not matched by increases in total organic matter. Instead, if the rate at which organic $\mathrm{P}$ is converted to inorganic forms decreases, it would produce the patterns we report. P mineralization can occur via the production of extracellular phosphatases by plant roots [Speir and Cowling, 1991], therefore a change from forest to pasture vegetation may be partly responsible for a decline in mineralization rates. However, $\mathrm{P}$ mineralization by both 

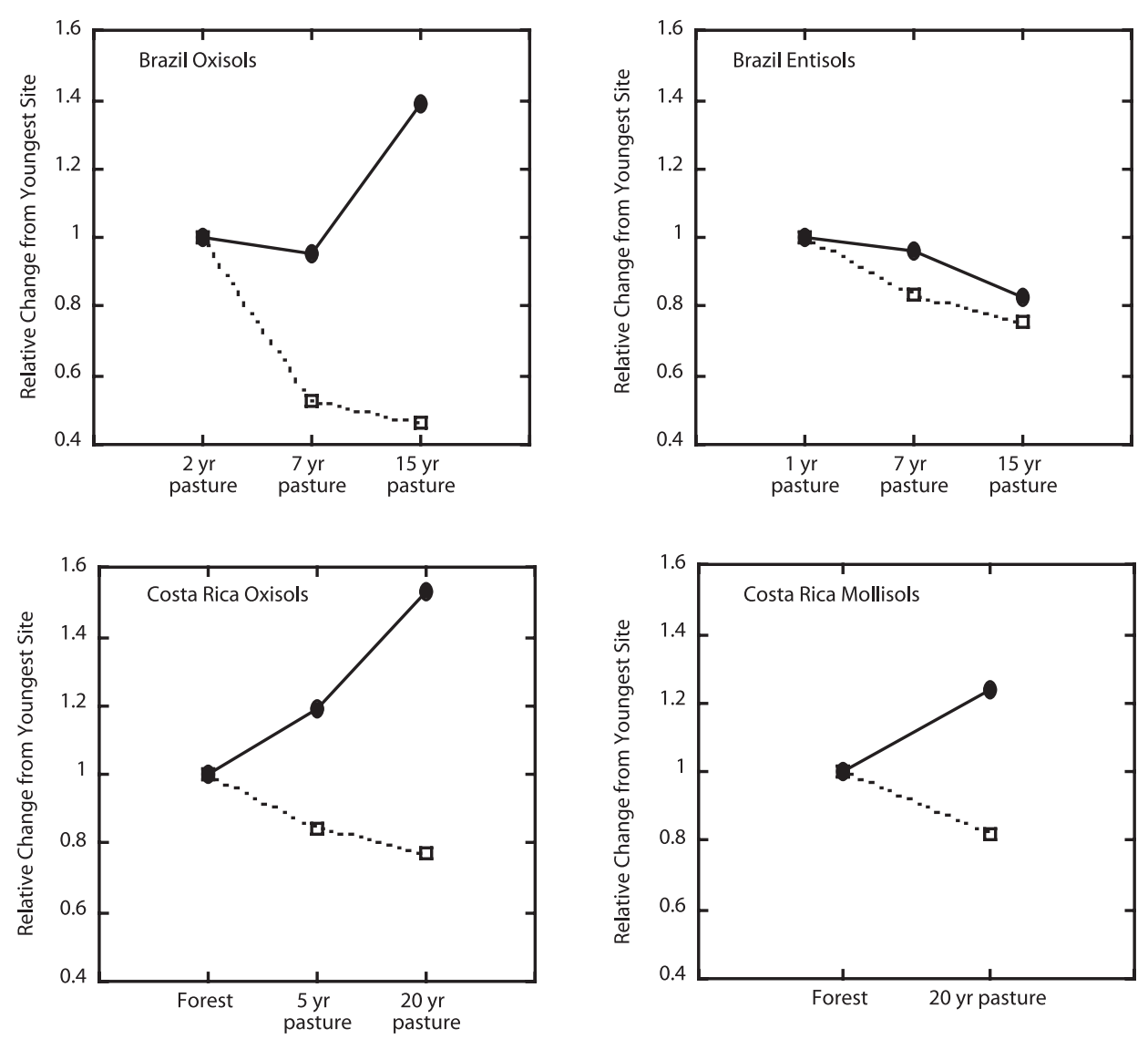

Figure 4. Relative changes in soil organic $\mathrm{C}$ (dashed line) and $\mathrm{P}$ (solid line) along each of the four chronosequences. Values are relative to the youngest site in each sequence, and are taken from data that measured each variable as a concentration (\% soil $\mathrm{C}, \mu \mathrm{g} \mathrm{P} / \mathrm{g}$ soil).

fungal and bacterial communities is enormously important, and several recent lines of evidence suggest that these communities may be heavily affected by forest-to-pasture conversion [Nüsslein and Tiedje, 1999; Borneman and Triplett, 1997; Atlas et al., 1991]. Data from our Costa Rican sites shows major declines in microbial biomass between forest and pasture, a lowered efficiency of the microbial biomass in response to added $\mathrm{C}$ and $\mathrm{P}$, and suggests changes in microbial community structure [Cleveland et al., 2002]. We believe that such disturbances to the microbial community may cause declines in P mineralization.

[31] Finally, we wish to stress that while we did find some surprisingly consistent patterns among our sites, the variation in climate, soil types, and management strategies they represent also created some major differences, exemplifying the danger of oversimplifying responses to land use change in the tropics. For example, in Costa Rica, where rainfall is high and the dry season short, burning was not used as a management tool, and the number of cattle per pasture was low, aging pastures displayed minor or no changes in major biogeochemical indices of fertility in either soil. In contrast, the Brazilian pastures, with a drier climate, repeated burning and higher numbers of cattle, showed declining pools of soil $\mathrm{C}, \mathrm{N}$ and $\mathrm{P}$, but the patterns and extent of loss varied considerably with soil type. We also note that while highly sandy soils such as the Entisols are not nearly as common in lowland tropical regions as Oxisols and Ultisols, land use is not always in direct proportion to the abundance of soil types. In particular, sandy soils are often found near sources of water, as they are throughout the Santarém region, making them desirable locations for pasture and agriculture despite their often poor fertility. The fact that we observed large and rapid declines in already low soil carbon and phosphorus pools in our Entisol pastures suggests that these sandy soils may be especially sensitive to land clearing and use.

[32] Acknowledgments. We thank G. Nardoto, G. Cardinot, B. Constance, L. Asner and M. Keller for their assistance in the field and laboratory. We also thank the Instituto Brasiliero do Meio Ambiente (IBAMA), the Minasterio de Ambiente and Energia (MINAE), the Organization for Tropical Studies, and H. and M. Michaud for logistical assistance. Discussions with E. Davidson, W. Silver and P. Vitousek were very helpful. This work was supported by NASA NIP grants NAGW-5253 and NAGW-8709.

\section{References}

Afif, E., V. Barron, and J. Torrent, Organic matter delays but does not prevent phosphate sorption by cerrado soils from Brazil, Soil Sci., 159, 207-211, 1995.

Anghinoni, I., V. C. Baligar, and R. J. Wright, Phosphorus sorption isotherm characteristics and availability parameters of Appalachian acidic soils, Commun. Soil Sci. Plant Anal., 27, 2033-2048, 1996.

Asner, G. P., A. R. Townsend, and M. C. Bustamante, Spectrometry of pasture condition and biogeochemistry in the Central Amazon, Geophys. Res. Lett., 26, 2769-2772, 1999. 
Atlas, R. M., A. Horowitz, M. Krichevsky, and A. K. Bej, Response of microbial populations to environmental disturbance, Microb. Ecol., 22 249-256, 1991 .

Beauchemin, S., R. R. Simard, and D. Cluis, Phosphorus sorption-desorption kinetics of soil under contrasting land uses, J. Environ. Qual., 25, $1317-1325,1996$.

Berrange, J. P., and R. S. Thorpe, The geology, geochemistry and emplacement of the Cretacous-Tertiary ophiolitic Nicoya Complex of the Osa Peninsula, southern Costa Rica, Tectonophysics, 147, 193-220, 1988.

Borneman, J., and E. W. Triplett, Molecular microbial diversity in soils from eastern amazonia, Appl. Environ. Microbiol., 63, 2647-2653, 1997.

Bowman, R. A., S. R. Olson, and F. S. Watanabe, Greenhouse evaluation of residual phosphate by four phosphorus methods in neutral and calcareous soils, Soil. Sci. Soc. Am. J., 42, 451-454, 1978.

Bruijnzeel, L. A., Nutrient input-output budgets of tropical forest ecosystems, J. Trop. Ecol., 7, 1-24, 1991.

Chadwick, O. A., et al., Changing sources of nutrients during four million years of ecosystem development, Nature, 397, 491-497, 1999.

Chauvel, A., M. Grimaldi, and D. Tessier, Changes in soil pore-space distribution following deforestation and revegetation: An example from the central Amazon Basin, Brazil, For. Ecol. Manage., 38, 259-271, 1991.

Cleveland, C. C., A. R. Townsend, B. C. Constance, and S. Schmidt, Soil microbial dynamics and biogeochemical cycling in lowland tropical rain forests and pastures of southwestern Costa Rica, Ecological Applications, in press, 2002.

Crews, T. E., K. Kitayama, J. Fownes, D. Herbert, D. Mueller-Dombois, R. H. Riley, and P. M. Vitousek, Changes in soil phosphorus and ecosystem dynamics across a long soil chronosequence in Hawai'i, Ecology, 76, 1407-1424, 1995.

Cross, A. F., and W. H. Schlesinger, A literature review and evaluation of the Hedley fractionation: Applications to the biogeochemical cycle of soil $\mathrm{P}$ in natural ecosystems, Geoderma, 64, 197-214, 1995.

Cuevas, E., and E. Medina, Nutrient dynamics within Amazonian forests, II, Fine root growth, nutrient availability and leaf litter decomposition, Oecologia, 76, 222-235, 1988.

Davidson, E. A., D. C. Nepstad, C. Klink, and S. E. Trumbore, Pasture soils as a carbon sink, Nature, 376, 472-473, 1995.

de Moraes, J. F. L., B. Volkoff, C. C. Cerri, and M. Bernoux, Soil properties under Amazon forest and changes due to pasture installation in Rondonia Brazil, Geoderma, 70, 63-81, 1996

Dias-Filho, M. B., E. A. Davidson, and C. J. R. de Carvalho, Biogeochemical cycles in Amazonian pastures, in The Biogeochemistry of the Amazon Basin, edited by M. E. McClain, R. L. Victoria, and J. E. Ritchey, Oxford Univ. Press, New York, 2001.

Ewel, J. J., M. J. Mazzarino, and C. W. Berish, Tropical soil fertility changes under monocultures and successional communities of different structure, Ecol. Appl., 1, 289-302, 1991.

Fearnside, P. M., Amazonian deforestation and global warming: Carbon stocks in vegetation replacing Brazilian Amazon forest, For. Ecol. Manage., 80, 21-34, 1996

Garcia-Montiel, D. C., C. Neiil, J. Melillo, S. Thoma, P. A. Steudler, and C. C. Cerri, Soil phosphorus transformations following forest clearing for pasture in the Brazilian Amazon, Soil Sci. Soc. Am. J., 64, 1792-1804, 2000 .

Graham, W. F., and R. A. Duce, Atmospheric pathways of the phosphorus cycle, Geochim. Cosmochim. Acta, 43, 1195-1208, 1979.

Guggenberger, G., L. Haumaier, R. J. Thomas, and W. Zech, Assessing the organic phosphorus status of an Oxisol under tropical pastures following native savanna using 31P NMR spectroscopy, Biol. Fertil. Soils, 23, 332-339, 1996.

Herbert, D. A., and J. H. Fownes, Phosphorus limitation of forest leaf area and net primary production on a highly weathered soil, Biogeochemistry, 29, 223-235, 1995 .

Houghton, R. A., D. L. Skole, C. A. Nobre, J. L. Hackler, K. T. Lawrence, and W. H. Chomentowski, Annual fluxes or carbon from deforestation and regrowth in the Brazilian Amazon, Nature, 403, 301-304, 2000.

Kauffman, J. B., D. L. Cummings, and D. E. Ward, Fire in the Brazilian Amazon: Biomass, nutrient pools and losses in slashed primary forests, Oecologia, 104, 397-411, 1995.

Kauffman, J. B., D. L. Cummings, and D. E. Ward, Fire in the Brazilian Amazon, 2, Biomass, nutrient pools and losses in cattle pastures, Oecologia, 113, 415-427, 1998.

Lesack, L. F. W., and J. M. Melack, Mass balance of major solutes in a rainforest catchment in the Central Amazon: Implications for nutrient budgets in tropical rainforests, Biogeochemistry, 32, 115-142, 1996.

Levy, E. T., and W. S. Schlesinger, A comparison of fractionation methods for forms of phosphorus in soils, Biogeochemistry, 47, 25-38, 1999.
Lopez-Hernandez, I. D., and C. P. Burnham, The effect of $\mathrm{pH}$ on phosphate adsorption in soils, J. Soil Sci., 25, 207-216, 1974.

Matson, P. A., W. J. Parton, A. G. Power, and M. J. Swift, Agricultural intensification and ecosystem properties, Science, 277, 504-509, 1997.

Meyer, W. B., and B. L. Turner II, Human population growth and global land-use/cover change, Annu. Rev. Ecol. Syst., 23, 39-61, 1992.

Neill, C., J. M. Melillo, P. A. Steudler, C. C. Cerri, J. F. L. de Moraes, M. C. Piccolo, and M. Brito, Soil carbon and nitrogen stocks following forest clearing for pasture in the southwestern Brazilian Amazon, Ecol. Appl., 7 , $1216-1225,1997$.

Nepstad, D. C., et al., Large-scale impoverishment of Amazonian forests by logging and fire, Nature, 398, 505-508, 1999.

Nüsslein, K., and J. M. Tiedje, Soil bacterial community shift correlated with change from forest to pasture vegetation in a tropical soil, Appl. Environ. Microbiol., 65, 3622-3626, 1999.

Ojima, D. S., K. A. Galvin, and B. L. Turner II, The global impact of landuse change, Bioscience, 44, 300-304, 1994.

Parkinson, J. A., and S. E. Allen, A wet oxidation process suitable for the determination of nitrogen and mineral nutrients in biological materials, Commun. Soil Sci. Plant Anal., 6, 1-11, 1975.

Parrotta, J. A., J. K. Francis, and R. Rolo de Almeida, Trees of the Tapajos, Tech. Rep. IITF-1, U. S. For. Serv., Washington, D. C., 1995

Reiners, W. A., A. F. Bouwman, W. F. J. Parsons, and M. Keller, Tropical rain forest conversion to pasture: Changes in vegetation and soil properties, Ecol. Appl., 4, 363-377, 1994.

Sanchez, P. A., D. E. Bandy, J. H. Villachica, and J. J. Nicholaides, Amazon Basin soils: Management for continuous crop production, Science, 216, $821-827,1982$.

Silver, W. L., J. Neff, M. McGroddy, E. Veldkamp, M. Keller, and R. Cosme, Effects of soil texture on belowground carbon and nutrient storage in a lowland Amazonian forest ecosystem, Ecosystems, 3, 193-209, 2000.

Skole, D., and C. Tucker, Tropical deforestation and habitat fragmentation in the Amazon: Satellite data from 1978-1988, Science, 260, 19051910, 1993.

Sollins, P., G. P. Robertson, and G. Uehara, Nutrient mobility in variableand permanent-charge soils, Biogeochemistry, 6, 181-199, 1988.

Speir, T. W., and J. C. Cowling, Phosphatase activities of plants and soils: Relationship with plant productivity and soil $\mathrm{P}$ fertility indices, Biol. Fertil. Soils, 12, 189-194, 1991

Tiessen, H., and J. O. Moir, Characterization of available P by sequential extraction, in Soil Sampling and Methods of Analysis, edited by Carter, M. R., Lewis, Boca Raton, Fla., 1993.

Tiessen, H., I. H. Salcedo, and E. V. S. B. Sampaio, Nutrient and soil organic matter dynamics under shifting cultivation in semi-arid northeastern Brazil, Agric. Ecosyst. Environ., 38, 139-151, 1992.

Tiessen, H., E. Cuevas, and P. Chacon, The role of soil organic matter in sustaining soil fertility, Nature, 371, 783-785, 1994

Uehara, G., and G. Gillman, The Mineralogy, Chemistry, and Physics of Tropical Soils with Variable Charge Clays, Westview, Boulder, Colo., 1981.

Veldkamp, E., Organic carbon turnover in three tropical soils under pasture after deforestation, Soil Sci. Soc. Am. J., 58, 175-180, 1994.

Vitousek, P. M., and H. Farrington, Nutrient limitation and soil development: Experimental test of a biogeochemical theory, Biogeochemistry, 3, $63-75,1997$

Vitousek, P. M., and R. L. Sanford Jr., Nutrient cycling in moist tropical forest, Annu. Rev. Ecol. Syst., 17, 137-167, 1986.

Walker, T. W., and J. K. Syers, The fate of phosphorus during pedogenesis, Geoderma, 15, 1-19, 1976.

Williams, J., and C. J. Chartres, Sustaining productive pastures in the tropics: Managing the soil resource, Trop. Grasslands, 25, 73-84, 1991.

G. P. Asner, Department of Global Ecology, Carnegie Institution of Washington, Stanford, CA 94305, USA. (greg@globalecology.stanford. edu)

M. M. C. Bustamante, Departament de Ecologia, Universidade de Brasília, Universitario Darcy Ribeiro, CEP 70.919-970 Brasília-DF, Brazil. (mercedes@unb.br)

C. C. Cleveland and A. R. Townsend, Institute of Arctic and Alpine Research (INSTAAR), Campus Box 450, University of Colorado, Boulder, CO 80309, USA. (cory.cleveland@colorado.edu;alan.townsend@colorado. edu)

M. E. Lefer, Stratus Consulting, 1881 Ninth Street, Suite 201, Boulder, CO 80302, USA. (mlefer@stratusconsulting.com) 